\title{
An Indigenous Biosurfactant Producing Burkholderia cepacia with High Emulsification Potential towards Crude Oil
}

\section{Qadreyah Almatawah*}

Kuwait Institute for Scientific Research, Environment and Life Sciences Research Center, PO Box 24885 Safat, 13109, Kuwait

\begin{abstract}
In this study, the isolation of a potent indigenous biosurfactant-producing bacterium with potential value in enhanced bioremediation of oil-contaminated soil and oil tertiary recovery from the soil was investigated. An indigenous biosurfactant producing Gram-negative-rod-shaped bacterial strain (KISRQC) was isolated from oil-contaminated soil in Kuwait. The strain was able to reduce the surface tension below $41.1 \mathrm{mN} / \mathrm{m}$ with all tested hydrocarbons and had excellent emulsification activity toward crude oil. The strain was identified as Burkholderia cepacia. Crude biosurfactant extract from this strain was found to contain lipid with $94.9 \%$ unsaturated fatty acids. The crude biosurfactant extract was able to reduce the surface tension to $24.6 \mathrm{mN} / \mathrm{m}$ at concentration $2 \mathrm{~g} / \mathrm{l}$. Characterization of the crude biosurfactant extract activities indicated that it was stable when exposed to high and low temperatures for a reasonable time period (>month) and in the presence of $5 \% \mathrm{NaCl}$. The crude biosurfactant extract was effective in recovering $99 \%$ of the residual crude oil from oil-saturated sand packs. This study shows the ability of Burkholderia cepacia KISRQC to produce a highly stable biosurfactant with the strong emulsification ability towards crude oil from non-toxic material. Suggesting its potential for commercial exploitation for enhanced bioremediation of oil-contaminated soil and oil recovery from the soil.
\end{abstract}

Keywords: Bioremediation; Biosurfactant isolation; Burkholderia cepacia; Crude oil

\section{Introduction}

Burkholderia cepacia, earlier known as Pseudomonas cepacia, is a motile aerobic oxidase positive Gram-negative bacillus commonly found in moist environments and liquid reservoirs. The strain was first described in 1950 by Burkholder [1] as the cause of soft rot of onions. $B$. cepacia is now gaining increasing interest in agriculture, biotechnology, and medicine. The reason for this particular interest includes the organism's abilities to promote plant growth by antagonizing soil borne plant pathogens [2-4]; to degrade hydrocarbons and thus contribute in the bioremediation of contaminated soil and water [5,6]; and to cause opportunistic human infections, mostly in patients with chronic granulomatous disease $[7,8]$ and cystic fibrosis (CF) [9-12].

B. cepacia can degrade a wide variety of compounds as carbon and energy sources [13], including a variety of aromatic compounds [14,15] pesticides and herbicides [16]. It has the ability to degrade benzo(a) pyrene and other fused ring compounds [17], and biodegradation of heavy crude oil [18]. The organism had shown remarkable potential as an agent for environmental pollution bioremediation.

Biosurfactants are amphiphilic compounds produced on living surfaces frequently on microbial cell surfaces or excreted extracellularly with noticeable surface and emulsifying activities and have been described as anti-adhesive antimicrobial agents $[19,20]$. They contain hydrophilic and hydrophobic molecules that confer the ability to accumulate between fluid phases, hence reducing surface and interfacial tension at the surface and interface respectively [19,21]. Biosurfactants exhibit a broad variety of chemical structures such as lipopeptides and lipoproteins, glycolipids, lipopolysaccharides, phospholipids, fatty acids, and polymeric lipids $[22,23]$. In recent years, the importance of biosurfactants has increased remarkably as they became potential candidates for many marketing applications in the petroleum, pharmaceuticals, biomedical, and food processing industries [24]. They have many advantages over chemical surfactants including lower toxicity and higher biodegradability, healthier environmental compatibility, high selectivity, and effectiveness at extreme temperatures, salinities or $\mathrm{pH}$ values [24-27]. In the present study, the isolation of a potent biosurfactant-producing bacterium, Burkholderia cepacia strain KISRQC with potential value in microbial enhanced oil recovery is reported. The effects of carbon sources on biosurfactant production and the biosurfactant chemical nature were also investigated. Furthermore, Microbial Enhanced Oil Recovery (MEOR) suitability tests and stability of the biosurfactant to environmental stresses are presented in this study.

\section{Materials and Methods}

\section{Bacteria and growth conditions}

The microorganism used in this study, code name KISRQC, is a Gram-negative-rod-shaped bacterium isolated from oil-contaminated soil in Kuwait by previously described method [28]. The strain was identified as Burkholderia cepacia by MIDI Labs laboratories (USA) using 16S rRNA gene sequence similarity, which was performed using a Perkin-Elmer Applied Biosystem's MicroSeq ${ }^{\mathrm{TM}}$ microbial analysis software and database. The sequence determined for the $16 \mathrm{~S}$ rRNA gene resulted in $99.7 \%$ match with Burkholderia cepacia (Gene Bank accession no. KY047601). The strain was grown on minimal media containing (g/l distilled water): $\mathrm{Na}_{2} \mathrm{HPO}_{4}, 2.7 ; \mathrm{KH}_{2} \mathrm{PO}_{4}, 1.4 ; \mathrm{NaNO}_{3}, 3.0$; $\mathrm{K}_{2} \mathrm{SO}_{4}, 0.36 ; \mathrm{MgSO}_{4} \cdot 7 \mathrm{H}_{2} \mathrm{O}, 0.15 ; \mathrm{NaCl}, 0.1 ; \mathrm{FeSO}_{4} \cdot 7 \mathrm{H}_{2} \mathrm{O}, 0.0007 ; 1 \mathrm{ml} / \mathrm{l}$ trace elements solution containing the following (g/l): $\mathrm{ZnSO}_{4} \cdot 7 \mathrm{H}_{2} \mathrm{O}$, $0.525 ; \mathrm{MnSO}_{4} .4 \mathrm{H}_{2} \mathrm{O}, 0.2 ; \mathrm{CuSO}_{4} .5 \mathrm{H}_{2} \mathrm{O}, 0.705 ; \mathrm{Na}_{2} \mathrm{MoO}_{4} \cdot 2 \mathrm{H}_{2} \mathrm{O} ; 0.015$ $\mathrm{CoCl}_{2} \cdot 6 \mathrm{H}_{2} \mathrm{O}, 0.200 ; \mathrm{H}_{3} \mathrm{BO}_{3}, 0.015$; and $\mathrm{NiSO}_{4} \cdot 6 \mathrm{H}_{2} \mathrm{O}, 0.027$; and $3 \%$ yeast extract ( $\mathrm{pH}$ 7.0). Olive oil was added to the media as a carbon source at a concentration of $3 \%(\mathrm{v} / \mathrm{v})$. The strain was incubated at $37^{\circ} \mathrm{C}$ on the

*Corresponding authors: Qadreyah Almatawah, Kuwait Institute for Scientific Research, Environment and Life Sciences Research Center, PO Box 24885 Safat, 13109, Kuwait, Tel: 0096524989116; Fax: 0096524956659; E-mail: qmutawa@kisr.edu.kw

Received November 13, 2017; Accepted November 17, 2017; Published November 23, 2017

Citation: Almatawah Q (2017) An Indigenous Biosurfactant Producing Burkholderia cepacia with High Emulsification Potential towards Crude Oil. J Environ Anal Toxicol 7: 528. doi: 10.4172/2161-0525.1000528

Copyright: (c) 2017 Almatawah Q. This is an open-access article distributed under the terms of the Creative Commons Attribution License, which permits unrestricted use, distribution, and reproduction in any medium, provided the original author and source are credited. 
rotary shaker at $250 \mathrm{rev} / \mathrm{min}$ for $24-48 \mathrm{~h}$ and checked for biosurfactant production by measuring the reduction in culture-broth surface tension with tensiometer.

\section{Carbon source effect determination}

To determine the effect of the carbon source on biosurfactant production, KISRQC strain was grown in minimal media containing 3\% yeast extract and $3 \%$ olive oil and incubated at $37^{\circ} \mathrm{C}$ for $24 \mathrm{~h}$. The $24 \mathrm{~h}$ culture was used to inoculate minimal media containing $3 \%$ yeast extract and different carbon source ( $2 \%$ crude oil; $1 \%$ diesel; $2 \%$ hexadecane; $1 \%$ kerosene; $3 \%$ olive oil; $3 \%$ paraffin; $1 \%$ xylene) and incubated for $96 \mathrm{~h}$ at $37^{\circ} \mathrm{C}$. The growth was observed as an increase in absorbance at $660 \mathrm{~nm}$ and converted to $\mathrm{g} / \mathrm{l}$ based on a predetermined calibration curve. After the incubation period, the broths surface tensions, emulsion indexes, and cell concentrations were measured.

\section{Surface activity measurement}

Surface tension and critical micelle concentration (CMC) were measured by the Du Nouy ring method [29] using Kruess K10T tensiometer (Kruess, Optische-Mechanische Werlostatten, Hamburg, W. Germany) with a $6 \mathrm{~cm}$ diameter platinum-iridium ring. The CMC is defined as the surfactant concentration necessary to initiate micelle formation. There will be no further decrease in the surface tension upon reaching the CMC when anadditional surfactant is present. CMC was determined by diluting the whole culture broth and measuring the surface tension of each dilution [30,31]. The reciprocal of CMC is proportional to the total surface-active compound amount present in the solution and can be used as an approximate measure of biosurfactant concentration.

\section{Determination of emulsification activity}

The emulsification activity of the biosurfactant was determined by the addition of $6 \mathrm{ml}$ hexadecane to $4 \mathrm{ml}$ of the test broth or biosurfactant in a $15-\mathrm{ml}$ graduated tube. The mixture was mixed vigorously for $2 \mathrm{~min}$ and allowed to stand for $24 \mathrm{~h}$ at room temperature. The emulsification index $\left(\mathrm{E}_{24}\right)$ was calculated by dividing the measured height of the emulsion layer by the total height of the mixture and multiplying it by $100[29,32,33]$.

\section{Dry cell weight measurement}

Biomass dry weights were determined by measuring the culture optical density at $660 \mathrm{~nm}$, and then centrifugation of $100 \mathrm{ml}$ sample of the culture broths at $10,000 \mathrm{xg}$ for $10 \mathrm{~min}$. The pellet was washed twice with distilled water, re-suspended in $10 \mathrm{ml}$ of distilled water, filtered through a pre-washed and weighed 7-cm-diameter Whatman No.1 filter paper, placed on a pre-weighed aluminum dish, dried at $105^{\circ} \mathrm{C}$ overnight, and reweighed after $24 \mathrm{~h}$. A standard curve was constructed from the dry cell weights and their corresponding $\mathrm{OD}_{660}$ values.

\section{Biosurfactant extraction}

Cells in culture broth were disrupted by sonication for $15 \mathrm{~min}$ using an MSE $150 \mathrm{~W}$ ultrasonic disintegrator at 14 amplitude and centrifuged at $15,000 \mathrm{xg}$ for $15 \mathrm{~min}$ at $0^{\circ} \mathrm{C}$. The hydrophobic layer located at the surface was extracted using the methyl tertiary-butyl ether (MTBE)chloroform (1:1) solvent system. The solvent layer was separated from the aqueous phase and removed by rotary evaporation at $50^{\circ} \mathrm{C}$ under reduced pressure [34]. The resulting crude extract was stored at $-20^{\circ} \mathrm{C}$ for later analysis.

\section{GC analysis}

The fatty acid composition of the crude biosurfactant extracts was analyzed by Hewlett Packard HP5890 gas chromatograph, equipped with a flame ionization detector and a capillary column fused with methyl silicone ( $50 \mathrm{~m}$ length, $0.25 \mathrm{~mm}$ internal diameter). The operating temperature of the detector was $300^{\circ} \mathrm{C}$, and that of the injector was $280^{\circ} \mathrm{C}$. The column temperature was set at $120^{\circ} \mathrm{C}$ for the first $5 \mathrm{~min}$, then increased to $200^{\circ} \mathrm{C}$ at a rate of $5^{\circ} \mathrm{C} / \mathrm{min}$ and then increased again to $225^{\circ} \mathrm{C}$ at the rate of $4^{\circ} \mathrm{C} / \mathrm{min}$ until the final time $(35 \mathrm{~min})$.

\section{Stability studies}

The effects of several environmental parameters on the surface activity of the biosurfactant were determined. $\mathrm{NaCl}$ stability was determined by dissolving the crude biosurfactant in $5 \% \mathrm{NaCl}(200$ $\mu \mathrm{l} / 25 \mathrm{ml}$ ), and the surface tension was then measured. To determine the heat stability of the surface active compounds, the culture broth, the culture supernatant, the cell suspension, and the biosurfactant crude extract $(200 \mu \mathrm{l}$ in $25 \mathrm{ml} 0.9 \% \mathrm{NaCl})$ were heated at $100^{\circ} \mathrm{C}$ for $15 \mathrm{~min}$ and allowed to cool to room temperature, and the surface tension was then measured and compared to the corresponding values before heat treatment. Time stability was measured by incubating the biosurfactant crude extract at two different temperatures for five weeks, and the surface tension was then measured at one week intervals and compared to the corresponding values.

\section{Sandpack test}

A glass column (50 $\mathrm{ml}$ volume) was packed with acid washed sand (25-60 mesh $30 \mathrm{~g}$ ). The column was then saturated with $6 \mathrm{ml}$ crude oil and flooded with pore volumes of water until no further oil was released. The remaining residual oil was flooded with crude biosurfactant as a continuous flood of at least three pore volumes and released residual oil percentage was measured.

\section{Results}

\section{Effect of carbon source on biosurfactant production}

Table 1 showed the effect of carbon source on biosurfactant production. There were significant differences between the control and other tested carbon sources in the surface tension value. The surface tensions were below $41.1 \mathrm{mN} / \mathrm{m}$ for all tested carbon sources. Surface tension decreased from 41.1 to $27 \mathrm{mN} / \mathrm{m}$, with the greatest reduction (34\%) observed in culture enriched with $3 \%$ olive oil. Moreover, cell concentration was increased from $2.1 \mathrm{~g} / \mathrm{l}$ to $20.4 \mathrm{~g} / \mathrm{l}$ with olive oil enriched culture. Crude oil also showed an increase in cell concentration from $2.1 \mathrm{~g} / \mathrm{l}$ to $17.1 \mathrm{~g} / \mathrm{l}$. The best emulsion index was $70 \%$ when olive oil used as carbon source. The ability of culture broth enriched with 3\% olive oil to emulsify crude oil was tested. The broth was found to be able to emulsify crude oil (Figure 1).

\begin{tabular}{|c|c|c|c|}
\hline Carbon Source & $\mathbf{S T}(\mathbf{m N} / \mathbf{m})$ & $\mathbf{E}_{\mathbf{2 4}}(\%)$ & Cell Concentration $\mathbf{( g / l )}$ \\
\hline Control $^{*}$ & $41.1 \pm 0.3$ & $30.0 \pm 0$ & $2.1 \pm 0.08$ \\
\hline Crude oil $^{*}$ & $31.3 \pm 0.7$ & $25.0 \pm 15$ & $17.1 \pm 1.6$ \\
\hline Diesel & $30.9 \pm 0.4$ & $8.5 \pm 3.5$ & $5.8 \pm 0.8$ \\
\hline Hexadecane & $30.0 \pm 0.3$ & $7.5 \pm 2.5$ & $4.4 \pm 0.7$ \\
\hline Kerosen & $33.1 \pm 0.45$ & $5.5 \pm 0.5$ & $1.8 \pm 0.4$ \\
\hline Olive oil & $27.1 \pm 0.05$ & $70.0 \pm 0$ & $20.4 \pm 0.2$ \\
\hline Paraffin & $30.6 \pm 0.35$ & $10.0 \pm 5$ & $7.1 \pm 0.1$ \\
\hline Xylene & $32.0 \pm 1.8$ & 0 & $1.7 \pm 0.2$ \\
\hline
\end{tabular}

*Control containing minimal media, $3 \%$ yeast extract and bacteria

Table 1: Surface tensions (ST), emulsion index's $\left(E_{24}\right)$ and cells concentrations for KISRQC strain grown on different carbon sources. 


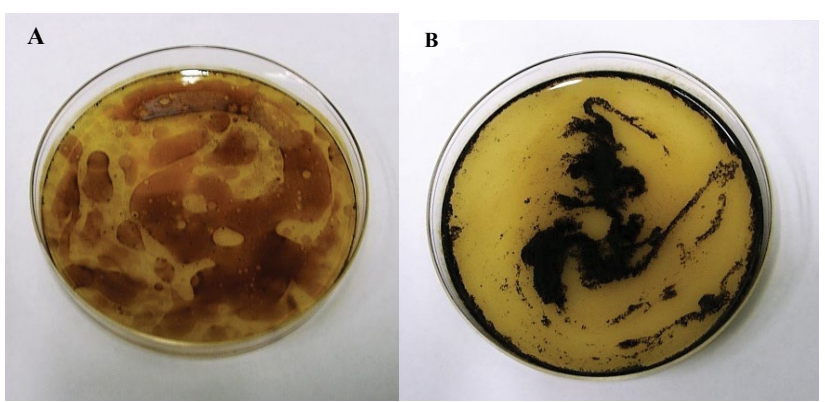

Figure 1: (A) Crude oil mixed with culture broth form KISRQC strain grown on minimal media only; (B) Crude oil mixed with culture broth form KISRQC strain grown on minimal media and $3 \%$ olive oil.

\section{Effect of incubation period on biosurfactant production}

The surface tension was monitored during the growth cycle of KISRQC strain to determine the optimum incubation period. The surface tension in the culture medium was found to be proportional to culture turbidity and biomass production (Figure 2). The reduction of culture surface tension occurred during the exponential growth in batch culture. The lowest value of surface tension $(26.8 \pm 0.1 \mathrm{mN} / \mathrm{m})$ was recorded $96 \mathrm{~h}$ after culture inoculation.

\section{Biosurfactant isolation}

To estimate the effectiveness of the biosurfactant concentrates, samples of culture broth were taken at the logarithmic phase of growth (48 hr) and extracted according to the method described earlier. The concentrates obtained were re-dissolved in $0.9 \% \mathrm{NaCl}$, and the surface tensions for a series of dilutions of them were measured (Figure 3 ). The biosurfactant crude extract was found to reduce the surface tension to $24.6 \pm 0.1 \mathrm{mN} / \mathrm{m}$ at a concentration of $2 \mathrm{~g} / \mathrm{l}$.

\section{Biosurfactant characterization}

The gas chromatography (GC/FID) analysis of the biosurfactant crude extract based on fatty acid showed that it contains saturated, and unsaturated fatty acids with the most predominate was the unsaturated fatty acid (Table 2). The fatty acid composition was C18:1 Trans (88\%), C18:2 Trans (5.6\%); C17:1 (5.0\%), C18:3A (1.03\%), C16:0 (0.32\%), and C14:0 (0.12\%). The biosurfactant crude extract was found to contain $14.4 \mathrm{~g} / \mathrm{l}$ lipid.

\section{Biosurfactant characterization}

The crude biosurfactant produced was characterized according to five criteria: the capacity to reduce surface tension, heat stability, $\mathrm{NaCl}$ stability, time stability, and the ability to mobilize oil from sand pack. The isolated crude biosurfactant was able to reduce the surface tension to $24.6 \pm 0.1 \mathrm{mN} / \mathrm{m}$. Table 3 shows the results of experiments on the effect of heat treatment on the biosurfactant activity for KISRQC culture. No significant change in biosurfactant activity occurred when culture broth, supernatant, cells, and biosurfactant crude extract were exposed to heat treatment. The properties of the biosurfactant present in all tested samples, i.e., surface tension, remained stable after exposure to high temperatures of $100^{\circ} \mathrm{C}$ for $15 \mathrm{~min}$.

Experimental results on the effect of $5 \% \mathrm{NaCl}$ on the surface tension and the emulsification ability of the biosurfactant on crude oil showed no significant change of the surface tension value $(27.1 \pm 0.6$ $\mathrm{mN} / \mathrm{m}$ ) and emulsification activity (Figure 4 ). The crude biosurfactant reduced $62.3 \%$ of the $5 \% \mathrm{NaCl}$ solution original surface tension. The

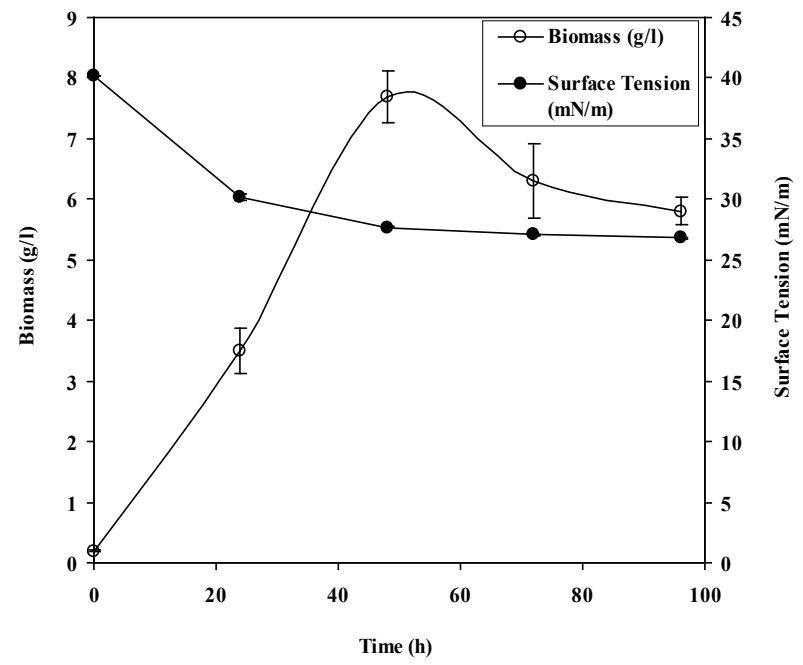

Figure 2: Growth curve for KISRQC strain showing the effect of incubation period at $37^{\circ} \mathrm{C}$ on biomass and culture broth surface tension.

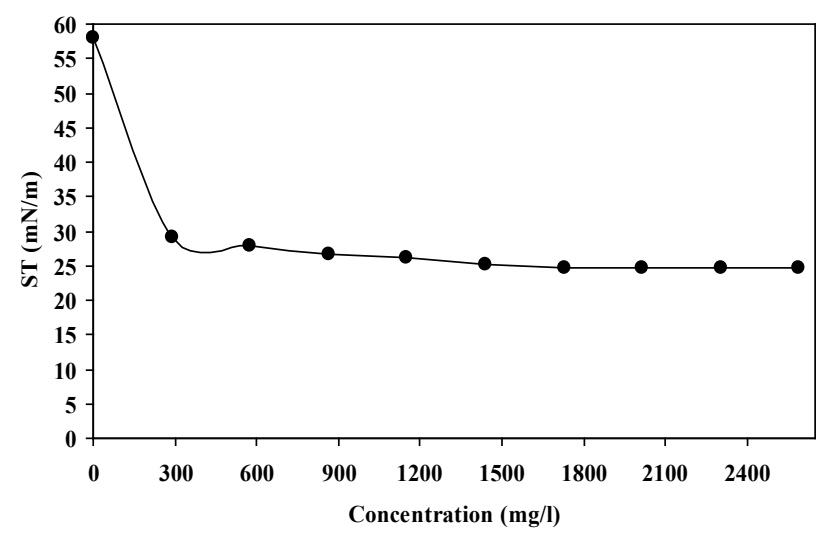

Figure 3: A plot for the surface tension versus the biosurfactant crude extract concentration.

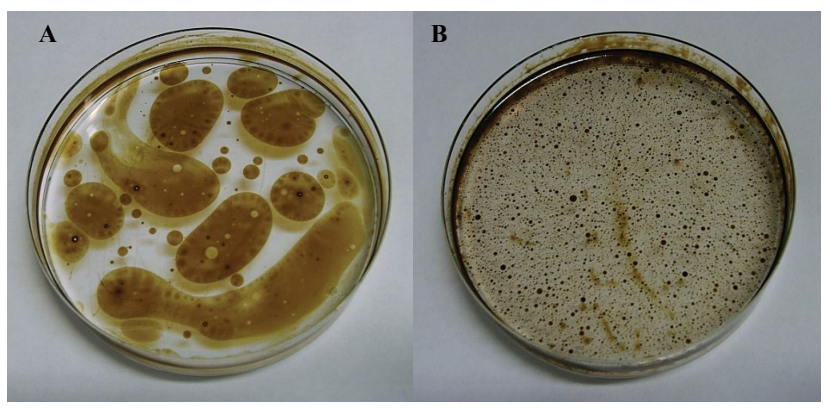

Figure 4: (A) Crude oil mixed with $5 \% \mathrm{NaCl}$ solution only; (B) Crude oil mixed with $5 \% \mathrm{NaCl}$ solution and $200 \mu \mathrm{l}$ biosurfactant crude extract.

biosurfactant properties remained stable for a reasonable time period under low temperature $\left(4^{\circ} \mathrm{C}\right)$ and high temperature $\left(45^{\circ} \mathrm{C}\right)$. After five weeks, the crude biosurfactant was able to reduce the surface tensions to $28.6 \pm 0.1 \mathrm{mN} / \mathrm{m}$ and $28.3 \pm 0.2 \mathrm{mN} / \mathrm{m}$ at $4^{\circ} \mathrm{C}$ and $45^{\circ} \mathrm{C}$ respectively. In sand pack experiments, the crude biosurfactant was found to be able to elute nearly $99 \%$ of the crude oil from the sand packs (Figure 5). 

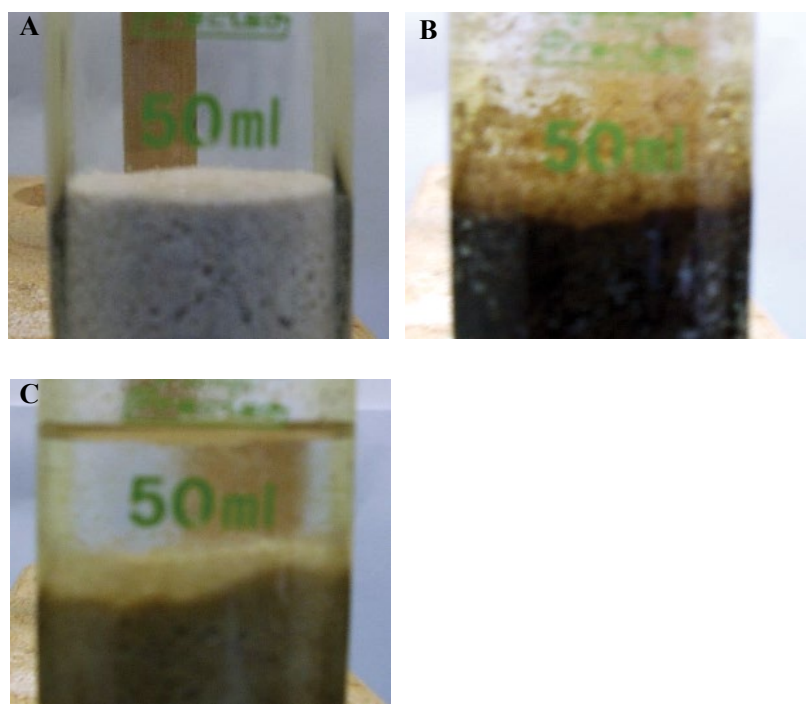

Figure 5: (A) Sand packed column containing only sea sand; (B) Sand packed column containing sea sand saturated with crude oil; (C) Sand packed column containing sea sand saturated with crude oil after three washes with biosurfactant crude extract.

\begin{tabular}{|c|c|}
\hline Fatty Acid Profile* & Area \% \\
\hline C14 & 0.12 \\
\hline C16 & 0.32 \\
\hline C17:1 & 5.0 \\
\hline C18:1 Trans & 88 \\
\hline C18:2 Trans & 5.6 \\
\hline C18:3 A & 1.03 \\
\hline
\end{tabular}

${ }^{*}$ C14 (Myristic); C16 (Palmitic); C17:1 (cis-10-Heptadecenoic); C18:1 Trans (Elaidic); C18:2 Trans (Linolelaidic); C18:3 A ( $\alpha$-Linolenic)

Table 2: Fatty acid composition for the crude KISRQC strain biosurfactant (\% of total fatty acids).

\begin{tabular}{|c|c|c|}
\hline Biosurfactant & $\begin{array}{c}\text { ST }(\mathbf{m N} / \mathbf{m}) \\
\text { Before Heat } \\
\text { Treatment }\end{array}$ & $\begin{array}{c}\mathbf{S T}(\mathbf{m N} / \mathbf{m}) \\
\text { After Heat Treatment }\left(\mathbf{1 0 0}{ }^{\circ} \mathbf{C} / \mathbf{1 5}\right. \\
\mathbf{m i n})\end{array}$ \\
\hline Culture Broth & $28.4 \pm 0.07$ & $26.9 \pm 0.04$ \\
\hline Culture Supernatant & $27.6 \pm 0.07$ & $26.6 \pm 0.14$ \\
\hline Cell Suspension & $27.8 \pm 0.07$ & $26.0 \pm 0$ \\
\hline $\begin{array}{c}\text { Biosurfactant Crude } \\
\text { Extract }\end{array}$ & $27.2 \pm 0.32$ & $27.8 \pm 0.21$ \\
\hline
\end{tabular}

Table 3: Heat stability for KISRQC strain biosurfactant.

\section{Discussion}

In recent years, several studies have shown that a number of Burkholderia species such as Burkholderia thailandensis [34,35], Burkholderia glumae [36], Burkholderia kururiensis [37], Burkholderia plantarii [38], and Burkholderia gladioli [39] were able to produce biosurfactant. However, the ability of Burkholderia cepacia to produce a biosurfactant was not sufficiently documented in the literature. Burkholderia cepacia was reported as one of the most predominant culturable species in crude oil and for their ability to degrade both aliphatic and aromatic hydrocarbons [40]. Limited studies have focused on the production of biosurfactant by Burkholderia cepacia. One study, show the inability of Burkholderia cepacia to produce a biosurfactant [41] and other studies showed its ability to produce a biosurfactant $[42,43]$. A study on the bioavailability of non-aqueous phase liquids (NAPLs) for Burkholderia cepacia, provided no evidence for the release of extracellular boisurfactants [41]. The study interrelated the release of lipopolysaccharides (LPS) in culture media for enhancement of cell surface hydrophobicity and adherence affinity to NAPLs. Another study reported the ability of Burkholderia cepacia MFW3 to produce biosurfactant when grown on whey waste water [42]. The biosurfactant was characterized as lipopeptide structure and reduced the surface tension by $12 \%$, with maximum emulsification activity of $59 \%$ with mineral oil. Moreover, a study also reported the ability of Burkholderia cepacia to produce an active surface agent [43]. In this study, the ability of Burkholderia cepacia KISRQC to produce an active biosurfactant is documented. The biosurfactant reduced the surface tension by $34 \%$, with maximum emulsification activity of $70 \%$ with hexadecane. Which is better than the previously reported results [42]. Furthermore, olive oil was found the best carbon source for the biosurfactant production. Pseudomonas fluorescens Migula 1895-DSMZ was reported to produce rhamnolipid biosurfactant with the highest yield when olive oil used as a carbon source [44]. Plant-derived oils have been documented as an excellent carbon substrates for biosurfactant production by Pseudomonas aeruginosa [45,46]. The Burkholderia gladioli culture produced most biosurfactant when enriched with $5 \%$ corn oil [39]. Burkholderia thailandensis produced a series of long chain rhamnolipids when grown in canola oil [35]. Although, diesel and hexadecane was also found to enhance biosurfactant production by Burkholderia cepacia KISRQC, one study reported the opposite [41]. This may be related to the application of different growth conditions.

The production of Burkholderia cepacia KISRQC biosurfactant is $2 \mathrm{~g} / \mathrm{l}$ when grown at $37^{\circ} \mathrm{C}$. This is nearly similar to the production of Burkholderia thailandensis E264 biosurfactant, $1.99 \mathrm{~g} / \mathrm{l}$ biosurfactant when grown at $30^{\circ} \mathrm{C}$ [35]. Burkholderia thailandensis E264 culture grown at $30^{\circ} \mathrm{C}$ generated a dry cell biomass throughout the growth period with $7.71 \mathrm{~g} / \mathrm{l}$ after $264 \mathrm{~h}$, whereas Burkholderia cepacia KISRQC culture grown at $37^{\circ} \mathrm{C}$ generated a dry cell biomass throughout the growth period with $7.7 \mathrm{~g} / \mathrm{l}$ after $48 \mathrm{~h}$. Burkholderia thailandensis E264 was found to produce di-rhamnolipids with C14-C14 chain length fatty acid moiety in most abundance $(41.88 \%)$ and others contained chains ranging from $\mathrm{C} 10-\mathrm{C} 12$ to $\mathrm{C} 16-\mathrm{C} 16$ chain length [34]. The potential of the long-chain rhamnolipids produced by Burkholderia species for lowering surface tension and decreasing the CMC was demonstrated [34]. Sophorolipids, a class of biosurfactants produced by Candida bombicola, was correlated it's decreasing of the CMC to carbon chain length. The additional $\mathrm{CH} 2$ groups were found to render the molecule more hydrophobic and facilitate micelle formation [47]. The ability of Pseudomonas aeruginosa to reduce the surface tension to $28.1 \mathrm{mK} / \mathrm{m}$ with maximum emulsification activity of $70 \%$ in culture medium enriched with $2 \%$ corn oil was reported [39]. Whereas, Burkholderia gladioli was found to reduce the surface tension to $45.4 \mathrm{mK} / \mathrm{m}$ with maximum emulsification activity of $69 \%$ in culture medium enriched with $5 \%$ corn oil. In this study, we reported the ability of Burkholderia cepacia KISRQC to reduce the surface tension to $27 \mathrm{mK} / \mathrm{m}$ with maximum emulsification activity of $70 \%$ in culture medium enriched with 3\% olive oil. Most of the reported biosurfactant from Burkholderia species were rhamnolipids that have long alkyl chains than those produced by Pseudomonas aeruginosa [48]. Interestingly, Burkholderia cepacia KISRQC biosurfactant crude extract was found to contain 14.4 g/l lipid with $\mathrm{C} 18$ unsaturated fatty acids in the highest abundance (94.9\%) followed by C17 (5\%), C16 (0.32\%) and C14 (0.12\%). The highest abundance of $\mathrm{C} 18$ fatty acid in Burkholderia cepacia KISRQC biosurfactant means that the biosurfactant structure is different from the reported biosurfactant from Burkholderia species. 
Citation: Almatawah Q (2017) An Indigenous Biosurfactant Producing Burkholderia cepacia with High Emulsification Potential towards Crude Oil. J Environ Anal Toxicol 7: 528. doi: 10.4172/2161-0525.1000528

Page 5 of 6

The isolated crude biosurfactant was able to reduce the surface tension, stable after exposure to high temperatures of $100^{\circ} \mathrm{C}$, and when incubated at $4^{\circ} \mathrm{C}$ and $45^{\circ} \mathrm{C}$ for five weeks. The production of biosurfactant was in the exponential growth phase, which indicates that the production of biosurfactant is a primary product of metabolism and suggests that it would be possible to be produced effectively in a continuous process. Since Kuwaiti soil contains high concentrations of sodium chloride and other salts, it is essential that a biosurfactant should be effective under these conditions. The surface tension and the emulsification ability of the biosurfactant on crude oil was found stable at $5 \% \mathrm{NaCl}$. Moreover, the crude biosurfactant extract was effective in recovering $99 \%$ of the residual crude oil from oil-saturated sand packs. Several researchers have been using sand pack columns for evaluation of surfactant suitability for enhanced oil recovery $[33,49,50]$.

So far, biosurfactants used has been limited due to the high cost of raw materials and processing. An inexpensive hydrophobic materials sources like vegetable oils or waste cooking oil and carbohydrates is a good approach for reducing industrial waste generation [51]. $B$. cepacia KISRQC seems a promising strain for large-scale biosurfactant production since it can grow on no toxic material such as olive oil; which is an advantage from an industrial point of view. Moreover, its biosurfactant showed a strong emulsification ability toward crude oil, suggesting its potential for commercial exploitation for enhanced bioremediation of oil-contaminated soil and oil recovery from the soil.

\section{Acknowledgements} (KISR).

This research work was funded by the Kuwait Institute for Scientific Research

\section{References}

1. Burkholder WH (1950) Sour skin, a bacterial rot of onion bulbs. Phytopathology 40: 115-117.

2. Hebbar KP, Davey AG, Dart PJ (1992) Rhizobacteria of maize antagonistic to Fusarium moniliforme, a soil-borne fungal pathogen: isolation and identification. Soil Biology and Biochemistry 24: 979-987.

3. Hebbar KP, Davey AG, Merrin J, McLoughlin TJ, Dart PJ (1992) Pseudomonas cepacia, a potential suppressor of maize soil-borne diseases-seed inoculation and maize root colonization. Soil Biology and Biochemistry 24: 999-1007.

4. McLoughlin TJ, Quinn JP, Bettermann A, Bookland R (1992) Pseudomonas cepacia suppression of sunflower wilt fungus and role of antifungal compounds in controlling disease. Appl Environ Microbiol 58: 1760-1763.

5. Folsom BR, Chapman PJ, Pritchard PH (1990) Phenol and trichloroethylene degradation by Pseudomonas cepacia G4: Kinetics and interactions between substrates. Appl Environ Microbiol 56: 1279-1285.

6. Okoh A, Ajisebutu S, Babalola, G, Trejo-Hernandez, MR (2001) Potential of Burkholderia cepacia RQ1 in the biodegradation of heavy crude oil. Int Microbiol 4: 83-87.

7. Lacy DE, Spencer DA, Goldstein A, Weller PH, Darbyshire P (1993) Chronic granulomatous disease presenting in childhood with Pseudomonas cepacia septicaemia. J Infect 27: 301-304.

8. O'Neil KM, Herman JH, Modlin JF, Moxon ER, Winkelstein JA (1986) Pseudomonas cepacia: an emerging pathogen in chronic granulomatous disease. J Pediatr 108: 940-942.

9. Anonymous edn (1992) Pseudomonas cepacian - more than a harmless commensal? Lancet 339: 1385-1386.

10. Govan JR, Deretic V (1996) Microbial pathogenesis in cystic fibrosis: Mucoid Pseudomonas aeruginosa and Burkholderia cepacia. Microbiol Rev 60: 539-574.

11. Isles A, MacLuskey I, Corey M, Gold R, Prober C, et al. (1984) Pseudomonas cepacia infection in cystic fibrosis: an emerging problem. J Pediatr 104: 206-210.

12. Simmonds EJ, Conway SP, Ghoneim ATM, Ross H, Littlewood JM (1990) Pseudomonas cepacia: a new pathogen in patients with cystic fibrosis referred to a large centre in the United Kingdom. Arch Dis Child 65: 874-877.
13. Lessie TG, Gaffney T (1986) Catabolic potential of Pseudomonas cepacian pp: 439-448.

14. Grifoll M, Selifonov SA, Gatlin CV, Chapman PJ (1995) Actions of a versatile fluorene-degrading bacterial isolate on polycyclic aromatic compounds. Appl Environ Microbiol 61: 3711-3723.

15. Revathy T, Jayasri MA, Suthindhiran K (2015) Biodegradation of PAHs by Burkholderia sp. VITRSB1 isolated from marine sediments. Scientifica.

16. Bhat MA, Tsuda M, Horiike K, Nozaki M, Vaidyanathan CS, et al. (1994) Identification and characterization of a new plasmid carrying genes for degradation of 2,4-dichlorophenoxyacetate from Pseudomonas cepacia CSV90. Appl Environ Microbiol 60: 307-312.

17. Juhasz AL, Britz ML, Stanley GA (1997) Degradation of benzo(a)pyrene, dibenz(a,h)anthracene and coronene by Burkholderia cepacia. Water Sci Technol 36: 45-51.

18. Velraeds MC, Van der Mei HC, Reid G, Busscher HJ (1996) Physicochemical and biochemical characterization of biosurfactants released from Lactobacillus strains. Colloids Surf. B Biointerfaces 8: 51-61.

19. Van Hamme JD, Singh A, Ward OP (2006) Physiological aspects: Part 1 in a series of papers devoted to surfactants in microbiology and biotechnology. Biotechnol Adv 24: 604-620.

20. Rodrigues LR, Teixeira JA, Van der Mei HC, Oliveira R (2006) Physicochemical and functional characterization of a biosurfactant produced by Lactococcus lactis 53. Colloids Surf. B Biointerfaces 49: 79-86.

21. Ahimou F, Jacques P, Deleu M (2000) Surfactin and iturin A effects on Bacillus subtilis surface hydrophobicity. Enzyme Microb Technol 27: 749-754.

22. Maier R, Soberon-Chavez G (2000) Pseudomonas aeruginosa rhamnolipids: Biosynthesis and potential applications. Appl Microbiol Biotechnol 54: 625-633.

23. Desai J, Banat I (1997) Microbial production of surfactants and their commercia potential. Microbiol Mol Biol Rev 61: 47-64.

24. Banat I, Franzetti A, Gandolfi I, Bestetti G, Martinotti M, et al. (2010) Microbia biosurfactants production, applications and future potential. Appl Microbiol Biotechnol 87: 427-444.

25. Cameotra SS, Makkar RS (1998) Synthesis of biosurfactants in extreme conditions. Appl Microbiol Biotechnol 50: 520-529.

26. Cameotra SS, Makkar RS, Kaur J, Mehta SK (2010) Synthesis of biosurfactants and their advantages to microorganisms and mankind. Adv Exp Med Biol 672 261-280.

27. Guerinik K, Al-Mutawah Q (2003) Isolation and characterization of oildesulphurizing bacteria. World J Microbiol Biotechnol 19: 941-945.

28. Abu-Ruwaida AS, Banat IM, Haditirto S, Salem A, Kadri M (1991) Isolation of biosurfactant-producing bacteria product characterization, and evaluation. Acta Biotechnol 11: 315-324.

29. Carrillo PG, Mardaraz C, Pitta-Alvarez SI, Giulietti AM (1996) Isolation and selection of biosurfactant-producing bacteria. World J Microbiol Biotechnol 12 82-84

30. Kim SH, Lim EJ, Lee SO, Lee JD, Lee TH (2000) Purification and characterization of biosurfactants from Nocardia sp. L-417. Biotechnol Appl Biochem 31: 249-253.

31. Cooper DG, Goldenberg BG (1987) Surface-active agents from two Bacillus species. Appl Environ Microbiol 53: 224-229.

32. Mohebali G, Ball A, Kaytash A, Rasekh B (2007) Stabilization of water/ gas oil emulsions by desulfurizing cells of Gordonia alkanivorans RIPI90A. Microbiology 153: 1573-1581.

33. Kuyukina MS, Ivshina IB, Philp JC, Christofi N, Dunbar SA, et al. (2001) Recovery of Rhodococcus biosurfactants using methyl tertiary-butyl ether extraction. J Microbiol Methods 46: 149-156.

34. Dubeau D, Déziel E, Woods DE, Lépine F (2009) Burkholderia thailandensis harbors two identical rhl gene clusters responsible for the biosynthesis of rhamnolipids. BMC Microbiol 9: 263.

35. Funston SJ, Tsaousi K, Rudden M, Smyth TJ, Paul SS, et al. (2016) Characterising rhamnolipid production in Burkholderia thailandensis E264, a non-pathogenic producer. Appl Microbiol Biotechnol 100: 7945-7956. 
Citation: Almatawah Q (2017) An Indigenous Biosurfactant Producing Burkholderia cepacia with High Emulsification Potential towards Crude Oil. J Environ Anal Toxicol 7: 528. doi: 10.4172/2161-0525.1000528

Page 6 of 6

36. Costa SG, Déziel E, Lépine F (2011) Characterization of rhamnolipid production by Burkholderia glumae. Lett Appl Microbiol 53: 620-627.

37. Tavares LFD, Silva PM, Junqueira M, Mariano DCO, Nogueira FCS, et al. (2013) Characterization of rhamnolipids produced by wild-type and engineered Burkholderia kururiensis. Appl Microbiol Biotechnol 97: 1909-1921.

38. Hoermann B, Müller M, Syldatk C, Hausmann R (2010) Rhamnolipid Production by Burkholderia plantarii DSM 9509T. Eur J Lipid Sci Technol 112: 674-680.

39. Catter KM, de Oliveira DF, de Sousa OV, Barros Gonçalves LR, dos Fernandes Vieira RHS, et al. (2016) Biosurfactant production by Pseudomonas aeruginosa and Burkholderia gladioli isolated from mangrove sediments using alternative substrates. Orbital: Electron J Chem 8: 269-275.

40. Yoshida N, Yagi K, Sato D, Watanabe N, Kuroishi T, et al. (2005) Bacterial communities in petroleum oil in stockpiles. J Biosci Bioeng 99: 143-149.

41. Mohanty G, Mukherji S (2008) Enhancement of NAPL bioavailability by induction of cell-surface hydrophobicity in Exiguobacterium aurantiacum and Burkholderia cepacia. Indian J Biotechnol 7: 295-30

42. Yilmaz F, Ergene A, Yalçin E, Tan S (2009) Production and characterization of biosurfactants produced by microorganisms isolated from milk factory wastewaters. Environ Technol 30: 1397-1404.

43. Ajao AT, Yakubu SE, Umoh VJ, Ameh JB (2014) Enzymatic studies and mineralization potential of Burkholderia cepacia and Corynebacterium kutscheri isolated from refinery sludge. J Microbiol Res 4: 29-42.
44. Abouseouda M, Maachib R, Amranec A, Boudergua S, Nabia A (2008) Evaluation of different carbon and nitrogen sources in production of biosurfactant by Pseudomonas fluorescens. Desalination 223: 143-151.

45. Rahman KS, Rahman TJ, McClean S, Marchant R, Banat IM (2002) Rhamnolipid biosurfactant production by strains of Pseudomonas aeruginosa using low-cost raw materials. Biotechnol Prog 18: 1277-1281.

46. Robert M, Mercadé ME, Bosch MP, Parra JL, Espuny MJ, et al. (1989) Effect of the carbon source on biosurfactant production by Pseudomonas aeruginosa 44T1. Biotechnol Lett 11: 871-874.

47. Zhang L, Somasundaran P, Singh SK, Felse AP, Gross R (2004) Synthesis and interfacial properties of sophorolipid derivatives. Colloids Surf A Physicochem Eng Asp 240: 75-82.

48. Díaz De Rienzo MA, Kamalanathan ID, Martin PJ (2016) Comparative study of the production of rhamnolipid biosurfactants by B. thailandensis E264 and P. aeruginosa ATCC 9027 using foam fractionation. Process Biochem 51: 820-827.

49. Bordoloi NK, Konwar BK (2008) Microbial surfactant-enhanced mineral oil recovery under laboratory conditions. Colloids Surf B: Biointerfaces 63: 73-82.

50. Gudiña EJ, Pereira JFB, Costa Rita, Coutinho JAP, Teixeira JA, et al. (2013) Biosurfactant-producing and oil-degrading Bacillus subtilis strains enhance oil recovery in laboratory sand-pack columns. J Hazard Mater 261: 106-113.

51. Sarrubo LA, Farias CBB, Campos-Takaki GM (2007) Co-utilization of canola oil and glucose on the production of a surfactant by Candida lipolytica. Curr Microbiol 54: 68-73. 